\title{
Home first aid applied by the mother for the treatment of food poisoning for children
}

\author{
Ali D. Abbas \\ Fundamentals of Nursing Department, College of Nursing, University of Baghdad, Baghdad, Iraq \\ Email: ali_dukhan@yahoo.com, alidukhan@uob.edu.iq
}

Received 29 July 213; revised 21 September 2013; accepted 15 October 2013

Copyright (C) 2013 Ali D. Abbas. This is an open access article distributed under the Creative Commons Attribution License, which permits unrestricted use, distribution, and reproduction in any medium, provided the original work is properly cited.

\begin{abstract}
Objective(s): The objectives of this study are to assess first aid home for the treatment of food poisoning among children by mother and to find out the relationship between first aid home for the treatment of food poisoning and the demographic characteristics including age of mother, level education of mother, mother's occupation, and family's income. Methodology: A descriptive analytical study was conducted on mother who applied home first aid for the treatment of food poisoning in her children. The study was conducted at the emergency unit in Children Welfare Teaching Hospital and Child's Central Teaching Hospital. Starting from 2nd Dec. 2012 up to the 15th Apr. 2013. To achieve the objectives of the study, a non-probability (purposive) sample of (60) mother reviewed the emergency unit for the treatment of food poisoning in her child suffering from food poisoning and according to special criteria. Data were collected by interview with mother of the child suffering from food poisoning. Instrument validity was determined through content validity, by a panel of experts. Reliability of the instrument was determined through the use of Pearson correlation coefficient for the test-retest approach, which was 0.85 . Analysis of data was performed through the application of descriptive statistics (frequency, percentage, and mean of score) and inferential statistics (correlation coefficient and one-way analysis of variance). Results: The results of the study indicated the level mean of scores related to first aid procedures relating to situations that food poisoning when the poisoning occurs and applied by mother was moderate level on half items and high level on half other from items. Conclusion: The study concluded most of mothers don't have prior knowledge of the procedures used for ambulance cases of food poisoning in children. Recommendations: The study recommend the need to set up educational sessions for
\end{abstract}

families especially the mother about how to first aid food poisoning in children and guide booklets or information sheet should be printed and distributed to mothers and families about food poisoning and first aid it, and these booklets or information sheet should be written in a simple style and handed out freely.

Keywords: Food Poisoning; Microbial Agents; Cross Contamination; World Health Organization

\section{INTRODUCTION}

Food poisoning includes ill effects caused by the ingestion of contaminated food by many ways apart from microbial agents. They may be

1) Through the addition of proteins,

2) Through eating of inherent poisonous substance such as certain mushrooms, fish and molluscs by mistake,

3) Adulteration of food with poisonous substance such as Argemone mexicana in mustard producing epidemic dropsy.

The term "food poisoning" is however restricted only to acute gastroenteritis due to bacterial pollution of food or drink. The term "food-borne" disease is defined as "A disease, usually either infectious or toxic in nature, caused by agents that enter the body through the ingestion of food" [1].

Food poisoning is a serious health problem. It can cause severe illness and even death. Food poisoning is frequently caused by bacteria from food that has been poorly handled, stored or cooked.

Each year thousands of people suffer from food poisoning. Eating or drinking contaminated food causes food poisoning. The food may be contaminated with bacteria, viruses or toxins. The most commonly reported types of food poisoning in this country are caused by Campylobacter and Salmonella bacteria [2].

Anyone can get food poisoning, but babies and tod- 
dlers are at especially high risk and once they become infected, young children can have a hard time getting well. Serious complications may develop, resulting in hospitalizations, lifelong health problems, and even death.

The World Health Organization (WHO) reports that each year two billion illnesses are caused by unsafe food; globally this number is growing.

In Asia, 700,000 people die each year as a result of food poisoning illnesses. Each year in the developing world, diarrhea illness from contaminated food and water causes 2 million deaths in young children. Most of these problems could be prevented with better science, prevention tools and by practicing good food hygiene [3].

Children tend to eat junk food in school, due to the appealing and mouth-watering aroma, and these foods that are showcased in the attractive way tend to entice school children. The coming-up of supermarkets and departmental stores has led to an increase in the quality of food supply, but people are still careless in the way they consume food. As a result, food poisoning occurs. Children suffer most on account of their weak immune system and unhealthy food habits.

Children should be warned against consuming foods, such as mushroom and seafood, which may cause food poisoning. Precaution should always be taken while preparing food. Food should be well-cleaned and well-cooked. Food poisoning can only be prevented by inculcating the right food habits in children [4].

\section{METHODOLOGY}

\subsection{Objective of the Study}

The study objectives are to assess first-aid home for the treatment of food poisoning among Children by mother and to find out the relationship between first-aid home for the treatment of food poisoning and the demographic characteristics include ( age of mother, level education of mother, mother's occupation, and family's income).

\subsection{Design of the Study}

A descriptive analytical study was conducted on mother who applied home first aid for the treatment of food poisoning in her children.

\subsection{Setting of the Study}

The study was conducted in emergency unit at two Teaching Hospitals in Baghdad city (Children Welfare Teaching Hospital and Child's Central Teaching Hospital) that reviewed by family of child suffering from food poisoning, especially the mother of child.

\subsection{Sample of the Study}

A non-probability (purposive) sample of (60) mother reviewed the emergency unit for the treatment of food poisoning in her child suffering from food poisoning according to the following criteria:

1) Children diagnosis with food poisoning and bring to emergency unit by mother.

2) Children with different age.

\subsection{Instrument Construction}

After extensive review of relevant literature, studies, the researcher constructed the questionnaire and was used as mean of data collection. It was comprised of three major parts.

\subsubsection{Part I: Demographic Characteristics}

The first part concerned with determination of the demographic characteristics through designated sheet which include seven items (mother's age, educational level of the parents, age of the child during the injury with food poisoning, gender of the child, working status of the mother, monthly a family income, ownership housing).

\subsubsection{Part II: Information about the Status of Food Poisoning}

This part is concerned with the Information related to status of food poisoning that consist from (8) items.

\subsubsection{Part III: First-Aid Procedures Relating to Situations Food Poisoning when the Poisoning Occurs}

This part is concerned with the first-aid procedures relating to situations food poisoning when the poisoning occurs that consist from (14) items. The items were ordinal according to the two level scale which were scored as $(\mathrm{No}=1$, and Yes $=2)$ for each level respectively so the cutoff point was (2).

\subsection{Validity of the Instrument}

Content validity was determined through the use of panel of experts.

\subsection{Reliability of the Instrument}

Pilot study was carried out between the 2nd to 31 st of Dec. 2012. On (5) mothers who reviewed the emergency unit for the treatment of food poisoning in her child who suffering from food poisoning by the researcher who used test-retest; "twice within two weeks" person correlation coefficient was computed for each determination. The results indicated that the correlation coefficient was $r$ $=0.85$ at the level $(\mathrm{P} \leq 0.01)$ which was statistically acceptable [5].

\subsection{Data Collection}

The data were collected by interview with mother of the 
child who suffering from food poisoning for the period from 13th Jan. to 4th Apr. 2013.

\subsection{Statistical Data Analysis}

Appropriate statistical approach is used that includes descriptive statistics (frequency, percentage, mean of score) and (correlation coefficient and one-way analysis of variance).

\section{RESULTS}

This table (Table 1) reveals that the majority $(46.7 \%)$ of Age of the mother were $(27-36)$ years old. (31.7\%) were graduated from intermediate School. The majority $(51.7 \%)$ of age of the child during the injury with food poisoning were $(2-4)$ years old. $(53.3 \%)$ were female. Concerning working status of the mother $(65 \%)$ wasn't working. In relation to monthly a family income $(53.3 \%)$ was adequate. (41.7\%) of ownership housing was property.

This table (Table 2) indicates that the majority (65\%) of mother have knowledge about signs and symptoms of food poisoning. While (53.3\%) of family members don't have prior knowledge of the procedures used for ambulance cases of food poisoning in children. (70\%) of mother say the procedure followed in the ambulance food poisoning was appropriate. (51.7\%) of the procedure followed in the ambulance food poisoning was directly in the house. $(80 \%)$ of child with food poisoning suffering don't have another disease.

The findings of this table (Table 3) indicated that the majority (45\%) of food poisoning was from eating packaged food.

The finding of this table (Table 4) show that the majority (36.7\%) of food poisoning was contains Plant and animal toxins.

The finding of this table (Table 5) revealed that the majority $(35 \%)$ of child during the injury with food poisoning the level of conscious was confounded.

The findings of this table (Table 6) indicated that the level of mean of score was moderate on item $(1,2,8,9$, 11,12 , and 14), while items $(3,4,5,6,7,10$, and 13) was high.

The findings in this table (Table 7) indicate that there are no significant difference between (age of mother, level education of mother, mother's occupation, and family's income) and First-aid procedures relating to situations food poisoning when the poisoning occurs by mother for her child at $(\mathrm{P} \leq 0.05)$.

\section{DISCUSSION}

Through the data analysis distribution of demographic variables Table 2 reports that most of the mother's children are (27 - 36) years old and this account for 28 $(46.7 \%)$ of the sample.
Table 1. Distribution of sample by their demographic characteristics.

\begin{tabular}{|c|c|c|c|}
\hline No. & Variables & & \\
\hline 1. & Age of the mother (years) & F & $\%$ \\
\hline 1.1. & $17-26$ & 15 & 25 \\
\hline 1.2. & $27-36$ & 28 & 46.7 \\
\hline 1.3. & $37-46$ & 16 & 26.7 \\
\hline \multirow[t]{2}{*}{1.4.} & 47 and more & 1 & 1.7 \\
\hline & Total & 60 & 100 \\
\hline 2. & Educational level of the mother & $\mathrm{F}$ & $\%$ \\
\hline 2.1. & Illiterate & 1 & 1.7 \\
\hline 2.2 . & Able to read and write & 1 & 1.7 \\
\hline 2.3 . & Primary School graduate & 10 & 16.7 \\
\hline 2.4 . & Intermediate School graduate & 19 & 31.7 \\
\hline 2.5 . & High School graduate & 14 & 23.3 \\
\hline \multirow[t]{2}{*}{2.6 . } & Institute and College graduate & 15 & 25 \\
\hline & Total & 60 & 100 \\
\hline 3. & $\begin{array}{l}\text { Age of the child during the injury } \\
\text { with food poisoning (years) }\end{array}$ & $\mathrm{F}$ & $\%$ \\
\hline 3.1. & $2-4$ & 31 & 51.7 \\
\hline 3.2 . & $5-7$ & 21 & 35 \\
\hline \multirow[t]{2}{*}{3.3 . } & $8-10$ & 8 & 13.3 \\
\hline & Total & 60 & 100 \\
\hline 4. & Gender of the child & $\mathrm{F}$ & $\%$ \\
\hline 4.1. & Male & 28 & 46.7 \\
\hline \multirow[t]{2}{*}{4.2 . } & Female & 32 & 53.3 \\
\hline & Total & 60 & 100 \\
\hline 5. & Working status of the mother & $\mathrm{F}$ & $\%$ \\
\hline 5.1 . & Working & 21 & 35 \\
\hline \multirow[t]{2}{*}{5.2.} & Not working & 39 & 65 \\
\hline & Total & 60 & 100 \\
\hline 6. & Monthly a family income & $\mathrm{F}$ & $\%$ \\
\hline 6.1 . & Adequate & 32 & 53.3 \\
\hline \multirow[t]{2}{*}{6.2.} & Not adequate & 28 & 46.7 \\
\hline & Total & 60 & 100 \\
\hline 7. & Ownership housing & $\mathrm{F}$ & $\%$ \\
\hline 7.1. & Rent & 18 & 30 \\
\hline 7.2 . & Property & 25 & 41.7 \\
\hline 7.3 . & Land for & 6 & 10 \\
\hline \multirow[t]{2}{*}{7.4 . } & Exceed & 11 & 18.3 \\
\hline & Total & 60 & 100 \\
\hline
\end{tabular}

$\mathrm{F}=$ frequency, $\%=$ percentage.

This result is similar to the results obtained from studies done by Logan, (2012). These results indicate that the majority of mother's children ages are early adulthood [6]. 
Table 2. Information about the status of food poisoning.

\begin{tabular}{|c|c|c|c|c|c|}
\hline \multirow{2}{*}{ No. } & \multirow{2}{*}{ Items } & Yes & No & \multicolumn{2}{|c|}{ Total } \\
\hline & & $\mathrm{F} \quad \%$ & $\%$ & $\mathrm{~F}$ & $\%$ \\
\hline 1. & Do you have knowledge of signs and symptoms of food poisoning? & 3965 & 2135 & 60 & 100 \\
\hline 2. & Does the family members prior knowledge of the procedures used for ambulance cases of food poisoning in children? & 2846.7 & 3253.3 & 60 & 100 \\
\hline 3. & Is the procedure followed in the ambulance food poisoning was appropriate? & 4270 & 1830 & 60 & 100 \\
\hline 4. & Is the procedure followed in the ambulance food poisoning was directly in the house? & 3151.7 & 2948.3 & 60 & 100 \\
\hline 5. & You had a child with food poisoning suffering from another disease? & 1220 & $48 \quad 80$ & 60 & 100 \\
\hline
\end{tabular}

$\mathrm{F}=$ frequency, $\%=$ percentage.

Table 3. Source of food poisoning in children.

\begin{tabular}{cccc}
\hline No. & Source & F & $\%$ \\
\hline 1 & Eating food prepared in the home & 12 & 20 \\
2 & Eating food prepared outside the home & 21 & 35 \\
3 & Eating packaged food & 27 & 45 \\
& Total & 60 & 100 \\
\hline
\end{tabular}

$\mathrm{F}=$ frequency, $\%=$ percentage.

Table 4. Contains of food poisoning.

\begin{tabular}{cccc}
\hline No. & Source & F & $\%$ \\
\hline 1. & Chemicals & 19 & 31.7 \\
2. & Plant and animal toxins & 22 & 36.7 \\
3. & Proliferation of micro-organisms & 19 & 31.7 \\
& Total & 60 & 100 \\
\hline
\end{tabular}

$\mathrm{F}=$ frequency, $\%=$ percentage.

Regarding educational level of the mother the majority of sample which account 19 (31.7\%) were graduated from intermediate School. This finding is similar to the results obtained from study done by Smith, (1998) [7].

Concerning the age of the child during the injury with food poisoning $31(51.7 \%)$ were $(2-4)$ years old. These findings are supported by Jacobs, (2001) [8].

With regard to gender of the child $32(53.3 \%)$ were female. This finding is similar to the results obtained from study done by Scallan, et al., (2012) [9].

Concerning working status of the mother 39 (65\%) wasn't working. In relation to monthly a family income $32(53.3 \%)$ was adequate. $25(41.7 \%)$ of ownership housing was property.

These results disagree with study done by Anderson, (2004) that indicate working status of the mother $(80 \%)$ was working. monthly a family income $(65.3 \%)$ was not adequate. (55\%) of ownership housing was property [3].

Table 3 indicates that the majority $(65 \%)$ of mother have knowledge about signs and symptoms of food poisoning. While (53.3\%) of family members don't have prior knowledge of the procedures used for ambulance cases of food poisoning in children.
Table 5. Level of conscious of the child during the injury with food poisoning.

\begin{tabular}{cccc}
\hline No. & Source & F & $\%$ \\
\hline 1. & Conscious & 17 & 28.3 \\
2. & Confounded & 21 & 35 \\
3. & Delirium & 3 & 5 \\
4. & Sleepy & 10 & 16.7 \\
5. & Stupor & 3 & 5 \\
6. & Unconscious & 6 & 10 \\
& Total & 60 & 100 \\
\hline
\end{tabular}

$\mathrm{F}=$ frequency, $\%=$ percentage.

These results disagree with study done by Malek, et al., (2005) that indicated $(80 \%)$ of mother has knowledge about signs and symptoms of food poisoning, and (82\%) of family members have prior knowledge of the procedures used for ambulance cases of food poisoning in children [10].

$(70 \%)$ of mother say the procedure followed in the ambulance food poisoning was appropriate. (51.7\%) of the procedure followed in the ambulance food poisoning was directly in the house. $(80 \%)$ of child suffering from food poisoning don't have another disease.

This result is supported by Gianella, (2006); they indicate that the majority of mother says the procedure followed in the ambulance food poisoning was appropriate and the procedure followed in the ambulance food poisoning was directly in the house. However (40\%) of child suffering from food poisoning have another disease [11].

Table 4 indicated that the majority 27 (45\%) of food poisoning was from eating packaged food. The result of present study agrees with study done by Doheny, (2013) that indicated the majority of food poisoning was from eating [12].

Table 5 show that the majority $22(36.7 \%)$ of food poisoning was contains Plant and animal toxins. The result of present study disagrees with study done by Newell, et al., (2010) that indicated the majority of food poisoning was contains chemicals toxins [4]. 
Table 6. The mean of scores and level mean of scores related to First-aid procedures relating to situations food poisoning when the poisoning occurs and applied by mother.

\begin{tabular}{|c|c|c|c|c|c|c|c|}
\hline No. & Items & Yes & & & No & & \\
\hline & & $\mathrm{F}$ & $\%$ & $\mathrm{~F}$ & $\%$ & MS & Level \\
\hline 1 & $\begin{array}{l}\text { Are summits to make sure of the symptoms and signs of } \\
\text { food poisoning by ambulance injured child? }\end{array}$ & 40 & 66.66 & 20 & 33.33 & 1.66 & M \\
\hline 2 & Are summits calling allocated for emergency evacuated to the hospital? & 23 & 38.33 & 37 & 61.66 & 1.38 & M \\
\hline 3 & Are summits to maintain airway and breathing for a child who suffers? & 52 & 86.66 & 8 & 13.33 & 1.86 & $\mathrm{H}$ \\
\hline 4 & Are summits to provide sufficient comfort for the injured child? & 59 & 98.33 & 1 & 1.66 & 1.98 & $\mathrm{H}$ \\
\hline 5 & Are summits Give adequate amounts of fluid for a child who suffers? & 54 & 90 & 6 & 10 & 1.9 & $\mathrm{H}$ \\
\hline 6 & Are summits to prevent solid foods for a child with? & 46 & 76.66 & 14 & 23.33 & 1.76 & $\mathrm{H}$ \\
\hline 7 & Are summits to prevent fried foods, fatty and sugary injured child? & 51 & 85 & 9 & 15 & 1.85 & $\mathrm{H}$ \\
\hline 8 & Are summits to prevent drinks containing caffeine for a child with? & 43 & 71.66 & 17 & 28.33 & 1.71 & $\mathrm{M}$ \\
\hline 9 & $\begin{array}{l}\text { Are summits using tea with lemon and ginger to relieve the } \\
\text { symptoms of food poisoning for a child who suffers? }\end{array}$ & 31 & 51.66 & 29 & 48.33 & 1.51 & M \\
\hline 10 & $\begin{array}{l}\text { After controlling nausea and vomiting Give Food Summits } \\
\text { fat-free light for a child who suffers? }\end{array}$ & 50 & 83.33 & 10 & 16.66 & 1.83 & $\mathrm{H}$ \\
\hline 11 & Are summits giving the anti-diarrhea medicine for a child who suffers? & 35 & 58.33 & 25 & 41.66 & 1.58 & M \\
\hline 12 & Are summits given the drugs for nausea and vomiting for a child who suffers? & 36 & 60 & 24 & 40 & 1.6 & M \\
\hline 13 & Are summits Give antipyretic drugs for a child who suffers? & 47 & 78.33 & 13 & 21.66 & 1.78 & $\mathrm{H}$ \\
\hline 14 & $\begin{array}{l}\text { Are summits Give rehydration solution (perfusion oral) when } \\
\text { continued vomiting and diarrhea for more than } 24 \text { hours? }\end{array}$ & 40 & 66.66 & 20 & 33.33 & 1.66 & $\mathrm{M}$ \\
\hline
\end{tabular}

$\mathrm{F}=$ frequency, $\%=$ percentage, $\mathrm{MS}=$ Mean of Score, $\mathrm{M}=$ Moderate, $\mathrm{H}=$ High.

Table 7. Analysis of variance for the difference between demographic characteristics and First-aid procedures relating to situations food poisoning when the poisoning occurs by mother for her child.

\begin{tabular}{|c|c|c|c|c|c|c|}
\hline Demographic characteristics & Source of variance & Sum of Squares & $\mathrm{df}$ & Mean Square & $\mathrm{F}$ & Sig. \\
\hline \multirow{3}{*}{ Age of mother } & Between Groups & 3.932 & 8 & 0.491 & \multirow{2}{*}{.811} & \multirow{2}{*}{0.596} \\
\hline & Within Groups & 30.918 & 51 & 0.606 & & \\
\hline & Total & 34.850 & 59 & & \multirow{4}{*}{.882} & \multirow{4}{*}{0.538} \\
\hline \multirow{3}{*}{ Level education of mother } & Between Groups & 10.087 & 8 & 1.261 & & \\
\hline & Within Groups & 72.896 & 51 & 1.429 & & \\
\hline & Total & 82.983 & 59 & & & \\
\hline \multirow{3}{*}{ Mother's occupation } & Between Groups & 1.611 & 8 & 0.201 & \multirow{2}{*}{.853} & \multirow{3}{*}{0.561} \\
\hline & Within Groups & 12.039 & 51 & 0.236 & & \\
\hline & Total & 13.650 & 59 & & \multirow{4}{*}{.629} & \\
\hline \multirow{3}{*}{ Family's income } & Between Groups & 1.341 & 8 & 0.168 & & \multirow{3}{*}{0.750} \\
\hline & Within Groups & 13.593 & 51 & 0.267 & & \\
\hline & Total & 14.933 & 59 & & & \\
\hline
\end{tabular}

$\mathrm{df}=$ Degree of freedom, $\mathrm{F}=\mathrm{F}$-statistics, Sig. = level of Significance.

Table 6 revealed that the majority $21(35 \%)$ of child during the injury with food poisoning the level of conscious was confounded. This result agrees with results done by Sodha, et al. (2010) which indicated the majority of child during the injury with food poisoning the level of conscious was confounded [13].
The study shows the level of mean of score was moderate on item (Are summits to make sure of the symptoms and signs of food poisoning by ambulance injured child? Are summits calling allocated for emergency evacuated to the hospital? Are summits to prevent drinks containing caffeine for a child with? Are summits using 
tea with lemon and ginger to relieve the symptoms of food poisoning for a child who suffers? Are summits giving the anti-diarrhea medicine for a child who suffers? Are summits given the drugs for nausea and vomiting for a child who suffers? And are summits Give rehydration solution (perfusion oral) when continued vomiting and diarrhea for more than 24 hours?).

While items (Are summits to maintain airway and breathing for a child who suffers? Are summits to provide sufficient comfort for the injured child? Are summits Give adequate amounts of fluid for a child who suffers? Are summits to prevent solid foods for a child with? Are summits to prevent fried foods, fatty and sugary injured child? After controlling nausea and vomiting Give Food Summits fat-free light for a child who suffers? And are summits Give antipyretic drugs for a child who suffers?) was high in Table 6.

This result agrees with results obtained from study done by Longphre, et al. (2007) which indicated that most of items related to First-aid procedures relating to situations food poisoning when the poisoning occurs was moderate level mean of scores [14].

Analysis of the result of the study shows that there are no significant difference between (age of mother, level education of mother, mother's occupation, and family's income) and First-aid procedures relating to situations food poisoning when the poisoning occurs by mother for her child at $(\mathrm{P} \leq 0.05)$ in Table 7.

This result disagrees with study done by Craig, and Zich, (2009), which showed that there is significant relationship between level education of mother and First aid procedures relating to situations food poisoning when the poisoning occurs by mother for her child [15].

\section{CONCLUSION}

The study concluded most of mothers don't have prior knowledge of the procedures used for ambulance cases of food poisoning in children.

\section{RECOMMENDATIONS}

1) Health education with focusing on the effect of food poisoning and how to first aid it through TV programs, radio, newspaper, and medical magazines, etc. should be increased

2) Educational sessions for families especially the mother about how to first aid food poisoning in children should be setting up.

3) Guide booklets or information sheet should be printed and distributed to mothers and families about food poisoning and first aid it, and these booklets or information sheet should be written in a simple style and handed out freely.

\section{ACKNOWLEDGEMENTS}

Before all, greatest thanks to "God" the Glorious, the Merciful, and the
Compassionate. I wish to express my deepest and grateful thanks and gratitude to Dr. Rabia M. Ali the dean of the College of Nursing University of Baghdad for his kindness and support.

\section{REFERENCES}

[1] Vijaya, K. (2008) Food microbiology ramesh. MJP Publishers, Chennai.

[2] U.S. Department of Agriculture Food Safety and Inspection Service (2006) Fact sheet. Safe food handling: Basics for handling food safely.

[3] Anderson, W. (2004) Food-borne and water-borne diseases. In: Tintinalli, J.E., Ed., Emergency Medicine: A Comprehensive Study Guide. 6th Edition, McGraw-Hill, New York, 964-969.

[4] Newell, D., et al. (2010) Food-borne diseases - The challenges of 20 years ago still persist while new ones continue to emerge. International Journal of Food Microbiology, 139, S3-S15. http://dx.doi.org/10.1016/i.ijfoodmicro.2010.01.021

[5] Bedworth, A. (1995) The profession and practice of health education. W.N.C. Brown Publishers, St. Louis, 304-306.

[6] Logan, N. (2012) Bacillus and relatives in foodborne illness. Journal of Applied Microbiology, 112, 417-29.

[7] Smith, J. (1998) Foodborne illness in the elderly. Journal of Food Protection, 61, 1229-39.

[8] Jacobs, R. (2001) General problems in infectious diseases: acute infectious diarrhea. In: Tierney Jr., L.M., McPhee, S.J. and Papadakis, M.A., Eds., Current Medical Diagnosis and Treatment, 40th Edition, McGraw-Hill, New York, 1215-1216.

[9] Scallan, E, et al. (2012) Foodborne illness acquired in the United States-Major pathogens. Emerging Infectious Diseases, 17, 7-15.

[10] Malek, M., et al. (2009) Outbreak of norovirus infection among river rafters associated with packaged delicatessen meat, Grand Canyon, 2005. Clinical Infectious Diseases, 48, 31-37.

[11] Gianella, R. (2006) Infectious enteritis and proctocolitis and bacterial food poisoning. Sleisenger and Fordtran's Gastrointestinal and Liver Disease, 2, 2333-2391.

[12] Doheny, K. (2013) Most common foods for foodborne illness: CDC report. Medscape Medical News, January 30.

[13] Sodha, S., et al. (2010) Foodborne disease. In: Mandell, G.L., et al., Eds., Mandell, Douglas, and Bennett's Principles and Practice of Infectious Diseases, 7th Edition, Churchill Livingstone Elsevier, Philadelphia, 413-1427

[14] Longphre, J. (2007) First aid normobaric oxygen for the treatment of recreational diving injuries. Undersea and Hyperbaric Medicine, 34, 43-49.

[15] Craig, S. and Zich, D. (2009) Gastroenteritis. In: Marx, J.A., Ed., Rosen's Emergency Medicine: Concepts and Clinical Practice. 7th Edition, Mosby Elsevier, Philadelphia, chap 92. 